Original Research Paper

\title{
Design, Fabrication and Operational Evaluation of a Co- Pyrolysis System for Waste-Plastics Derived Fuels: A Study of Edo North
}

\author{
${ }^{1}$ Kevin Otoikhian, ${ }^{1}$ Ubani Oluwaseun Amune, ${ }^{1}$ Kennedy Edogamhe, \\ ${ }^{2}$ Barnabas Agbodekhe, ${ }^{1}$ Kenneth Adama' and ${ }^{1}$ Emmanuel Aluyor \\ ${ }^{1}$ Department of Chemical Engineering, Edo State University, Iyamho-Uzairue, Edo State, Nigeria \\ ${ }^{2}$ University of Notre Dame, Southbend, Indiana, Notre Dame, IN 46556, USA
}

\author{
Article history \\ Received: 26-10-2021 \\ Revised: 06-11-2021 \\ Accepted: 11-12-2021 \\ Corresponding Author: \\ Kevin Otoikhian \\ Department of Chemical \\ Engineering, Edo State \\ University, Iyamho-Uzairue, \\ Edo State, Nigeria \\ Email: otoikhian.kevin@edouniversity.edu.ng
}

\begin{abstract}
This research work designed, developed, and assessed the performance of a co-pyrolysis system generating waste-plastic extract fuels from mixed Municipal Waste Plastics (MWP) while evaluating HighDensity Polyethylene (HDPE), Polypropylene (PP), and Polystyrene (PS) as the main municipal waste plastic sources. The materials selected for the reactor were carefully studied to meet the pyrolysis system's strength, operability, and safety requirements. The equipment was put through its paces in three trials, using $2 \mathrm{~kg}$ of mixed municipal waste plastics each. The temperature was optimally constant at $450^{\circ} \mathrm{C}$ for three hours. The equipment had a functional conversion efficiency (wt \%) of $73.17 \%$, a waste reduction efficiency (wt \%) of $86.3 \%$, and oil recovery of $0.90 \mathrm{~L}$ oil $/ \mathrm{kg} \mathrm{MWP}$, according to the test results. As a result of its re-cracking process, which recycles heavy molecular weight compounds back into the reactor, this reactor was built in such a manner that only compounds in the carbon range of $\mathrm{C}_{1} 20$ may be created. This process was discovered to have a major impact on the product's distribution. Plastic fuels generated from co-mingled municipal waste plastics had similar characteristics to diesel and based on the characterization and comparative research done in this study.
\end{abstract}

Keywords: Waste Plastic, Pyrolysis, Fabrication, Operability Study, Efficient Production, Characterization

\section{Introduction}

Plastics are manufactured from petrochemical hydrocarbons with stabilizers, oxidants, and flame retardants added as needed. Plastics are, therefore, nonbiodegradable and will endure for thousands of years in the environment (Ma et al., 2017). The consumption of plastics in Nigeria has grown annually by $7.8 \%$ over the past ten years, starting with 578 kilotonnes in 2007 to 1.229 kilotonnes in 2017 and this figure is predicted to be about 1.533 kilotonnes by 2020 (Asoko, 2017). The problem of disposing of generated waste plastics, as well as the environmental consequences, has drawn much attention from the general populace and academia (Jambeck et al., 2015). The most recent problem is the presence of solid plastic waste being a significant component of Municipal Waste (MSW), thereby blocking drainages, polluting water, and serving as breeding grounds for predators and disease-causing organisms (Amenaghawon et al., 2013). Amongst several options for curbing this menace is turning these waste plastics into feedstock for new products; thus, by combining waste control and material recycling, a continuous economy can be produced (Scheirs and Kaminsky, 2006). The techniques that convert waste from plastics into fuel vary widely dependent on the kind and grades of plastics to be converted and the characteristics of other wastes that may be utilized in the process (Williams and Slaney, 2007). In addition, effective conversion technologies are hinged on the selection of plastics according to the local economy, social, technical, and environmental characteristics. Generally, plastics are classified into two major types: Thermoplastics and thermosets. Low-Density Polyethylene (LDPE), High-Density Polyethylene 
(HDPE), Polypropylene (PP), Polycarbonate (PC), Polystyrene (PS), Polyvinyl Chloride (PVC), Polyethylene Terephthalate (PET) and Polymethyl Methacrylate (PMM) are among the thermoplastics (Aisien et al., 2021) while polyester, silicon, Polyurethane (PUR), vinyl ester and melamine resin are examples of thermosets (Kyaw and Hmwe, 2015). In descending order, the global average consumption of plastics is 7\% for PET, $10 \%$ for PS, $12 \%$ for other types of polymers, 13\% for PVC, 23 for PP, and 35\% for HDPE (Aisien et al., 2021). The most common plastics in waste polymer streams are polyolefins $(\mathrm{H}$ and LDPE, PP) and PS (Kyaw and Hmwe, 2015). The production of fuel from these plastic wastes holds a lot of present and future promises due to specific characteristics such as their higher heating value, properties similar to gasoline and diesel, and their environmental abundance (Aisien et al., 2021).

Among the various waste plastic management methods, pyrolysis is gaining popularity because it allows for the conversion of low-energy-density waste plastic materials into high-energy-density fuels and the recovery of high-value compounds (Panda, 2018). Pyrolysis, which is the thermal decomposition of materials in the absence of oxygen or the presence of inert gases alters the chemical composition while being among the most environmentally benign and promising treatments. By churning out a variety of products, the process massively reduces an enormous volume of waste, while lowering the decomposition temperature, cost of capital, and recovering a major part of the energy composition (Patni et al., 2013). Pyrolysis of PE, PP, and PS produces little or no solid unlike PET and PVC which leaves a small amount of solid residue (<10\%) (Matsuzawa et al., 2001). Thermal depolymerization, also known as pyrolysis, breaks long-chain polymers using heat at temperatures of about $\quad 400-600^{\circ} \mathrm{C}$. Instead of the polymer being broken down into its monomers, this process would produce shorterchain polymers, similar to products from crude oil fractioning thereby maximizing liquid production (Miandad et al., 2019). In a stirred semi-batch reactor at $400^{\circ} \mathrm{C}$, Kyong et al. (2002) studied the impact of wasted FCC catalyst on the pyrolysis of Low-Density Polyethylene (LDPE), High-density Polyethylene (HDPE), Polystyrene (PS), and Polypropylene (PP). The effectiveness of fresh FCC catalysts on PP plastic was studied by Abbas-Abadi et al. (2014). At optimal conditions of $450^{\circ} \mathrm{C}$ and a $10 \%$ catalyst ratio, they got a very high liquid oil yield of $92.3 \mathrm{wt} \%$. They finally concluded that the use of FCC catalyst at an optimal temperature of $450^{\circ} \mathrm{C}$ in plastic pyrolysis was recommended to increase liquid oil output.

The presence of large molecular weight compounds in the pyrolytic oil implies a massive cost and energy requirement for the separation of its fractions. This means that the useful fuels produced from waste plastics conversions have a low percentage and in turn, decrease the total pyrolysis system conversion rate. Environmental pollution in Edo state (feedstock availability and accessibility) and sorting costs have led to the development of this study project to design, fabricate and access the performance of a pyrolysis system that can handle a wide range of popular municipal waste materials and generate fuels from the pyrolysis system in the $\mathrm{C}_{11}-\mathrm{C}_{20}$ carbon range. The energy conservation is achieved through the re-cracking reflux of high molecular weight carbons thereby increasing the reactor temperature and encapsulating heat integration. The pyrolytic oil is physically characterized by the performance of the pyrolyzer.

\section{Materials and Methods}

\section{Pyrolyzer Design}

\section{Reactor Design}

The pyrolysis reactor was designed to have a cylindrical cross-section positioned vertically with a core inserted in a squared box to prevent external air interference. The height of the reactor and its thickness were 300 , and $8 \mathrm{~mm}$ respectively with internal and external diameters of 160 and $250 \mathrm{~mm}$. The internal pressure was 1.2 MPa (10.2 bar), Corrosion Allowance (CA) was $1.5 \mathrm{~mm}$, shell Internal Diameter (I.D) was 180 $\mathrm{mm}$, allowable stress (S) was $70 \mathrm{Mpa}$, the static head was $0.05 \mathrm{MPa}$ and joint efficiency(I) was $70 \%$. The design pressure allowed between 1.25-3.32 $\mathrm{MPa}$, and the corroded diameter was $187.5 \mathrm{~mm}$ with the maximum allowable pressure being. The reactor casing (box) had length, breadth, and height dimensions of $300 \mathrm{~mm}$ each. The reactor walls were made of mild steel because of their strength, high melting point, and low cost. The reactor base and box were alternatively made with stainless steel because of their higher thermal conductivity high melting point, lower corrosion vulnerability, and higher tensile strength. The heat source was positioned $300 \mathrm{~mm}$ below the cylindrical core inside the reactor box with a burner measuring $4 \mathrm{~mm}$ using LPG as fuel. The efficiency of the burner was $51.3 \%$. The reactor was designed to operate at considerable high pressure. Specific spots were located to attach pressure gauge, to connect piping for guiding vapor to the condenser, pressurizing cylinder, Vacuum pump, and a fabricated gas sampling tube. Two flanges, $10 \mathrm{~mm}$ thick served as the reactor cover sealing the reactor perfectly when subjected to high temperature and ensuring safety. Figure 1 and 2 shows the orthographic and pictorial views of the reactor, box, and heat supply.

\section{Condenser Design}

Figure 3 describes pictorially and orthographically the heat exchangers used in the condensation process. Two condensers were used for the vaporized fractions of the resultants. The first (shell and tube) was designed to have 5 tubes of $1 \mathrm{~m}$ in length each, using water as coolant and an inlet and outlet temperature of 15 and 
$60^{\circ} \mathrm{C}$ respectively while the second (tube-in-tube), arranged in a sequence was designed to have 1 tube of the same length, an inlet temperature of $25^{\circ} \mathrm{C}$ and outlet of $45^{\circ} \mathrm{C}$. The hot pyrolytic oil entering the first exchanger was at a maximum temperature of $500^{\circ} \mathrm{C}$ and exits at $287^{\circ} \mathrm{C}$ while the second entered at $287^{\circ} \mathrm{C}$ and exited at $62.5^{\circ} \mathrm{C}$. The overall heat transfer coefficient of the first heat exchanger was designed to be $33 \mathrm{~W} / \mathrm{m}^{2} \mathrm{~K}$, inner pipe $\left(\mathrm{H}_{\mathrm{i}}\right)$ coefficient was 414.46 $\mathrm{W} / \mathrm{m}^{2} \mathrm{~K}$, outer pipe heat transfer coefficient $\left(\mathrm{H}_{\mathrm{o}}\right)$ of $4,302.4 \mathrm{~W} / \mathrm{m}^{2} \mathrm{~K}$, and total heating rate $(\mathrm{Q})$ of $37,800 \mathrm{~W}$. The heat transfer area was $3.38 \mathrm{~m}$ with $1 \mathrm{~m}$ length each of the stainless steel tubes, the first heat exchanger was made of stainless steel (SS-304) $1 \mathrm{~mm}$ thick, the outer shell of galvanized pipe had a $1.5 \mathrm{~mm}$ thickness, inner stainless steel shell cover $2 \mathrm{~mm}$ thick while the second was made of aluminum (2 $\mathrm{mm}$ thick) all other parameters remaining unchanged. The overall heat transfer coefficient of the second exchanger was $201.56 \mathrm{~W} / \mathrm{m}^{2} \mathrm{~K}$, heat transfer coefficient based on inner pipe $\left(\mathrm{H}_{\mathrm{i}}\right)-977.5 \mathrm{~W} / \mathrm{m}^{2} \mathrm{~K}$, heat transfer coefficient of the outer pipe $\left(\mathrm{H}_{\mathrm{o}}\right)-3182.4 \mathrm{~W} / \mathrm{m}^{2} \mathrm{~K}$, the total rate of heat transfer (Q) $16,800 \mathrm{~W}$ and Area of $0.74 \mathrm{~m}$. Figures 4 and 5 give simulated and schematic views respectively of the pyrolysis system while the entire dimension of the pyrolysis system is given in Table 1 .
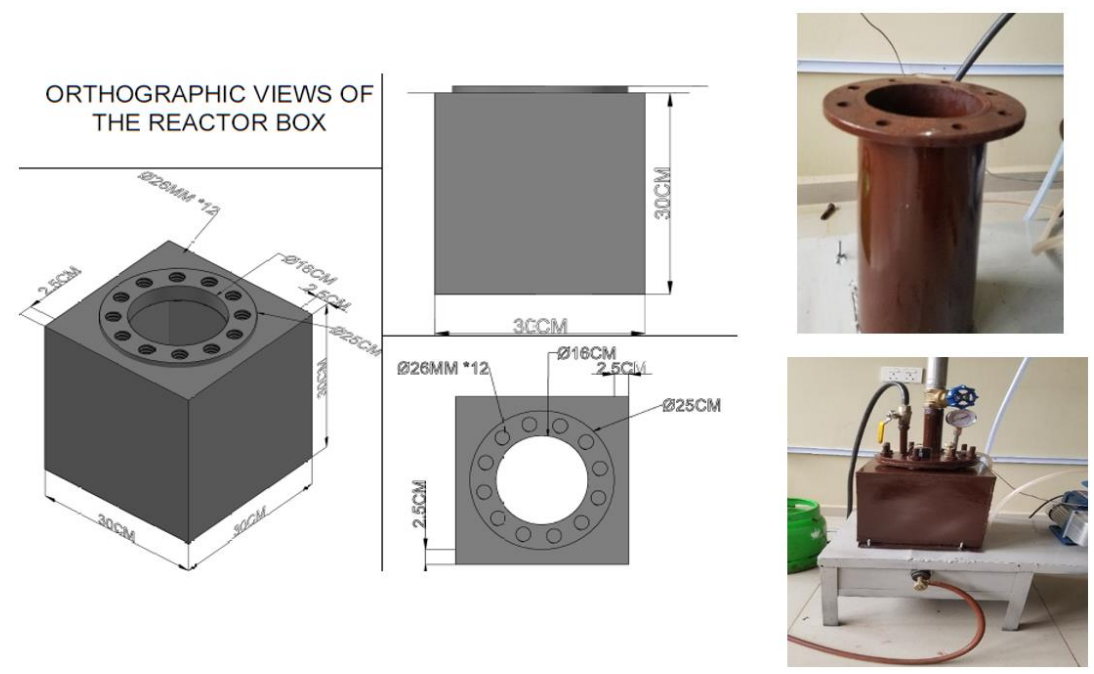

Fig. 1: Orthographic and pictorial view of the reactor and reactor box
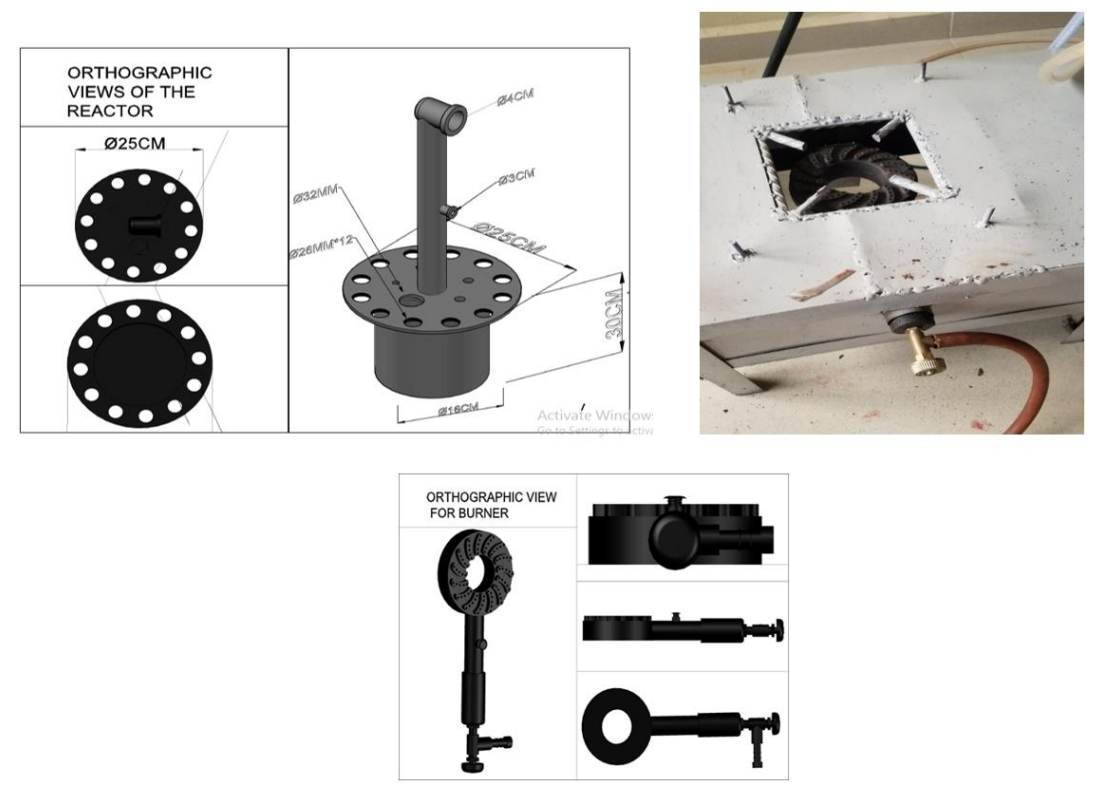

Fig. 2: Orthographic and pictorial view of the heat source 

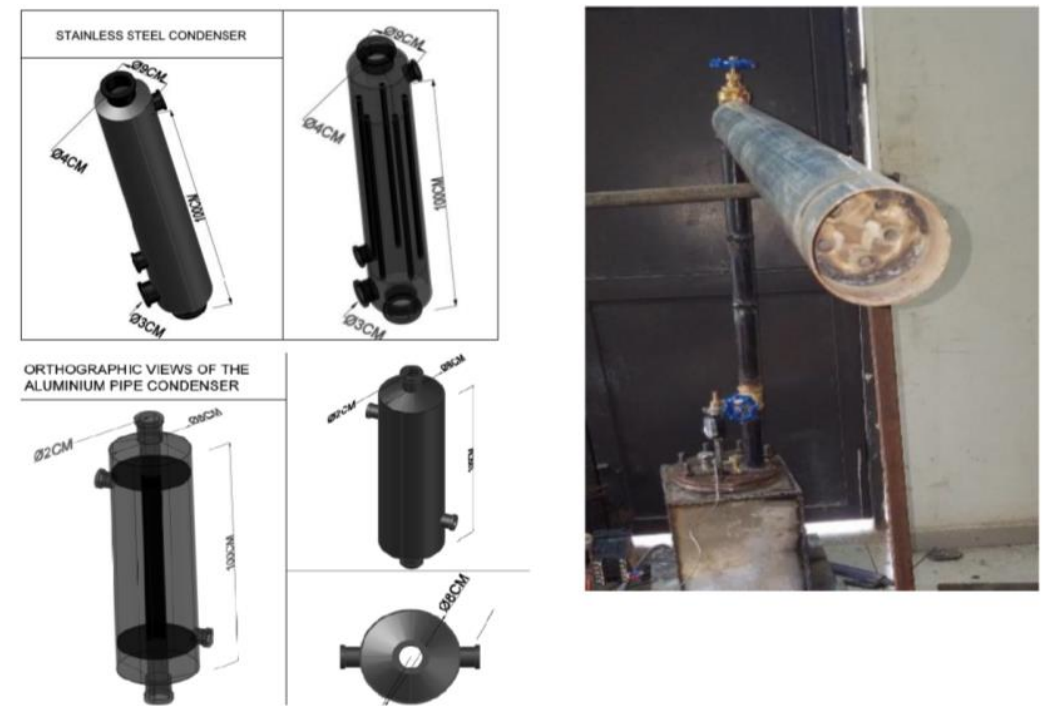

Fig. 3: Orthographic and pictorial view of heat exchangers

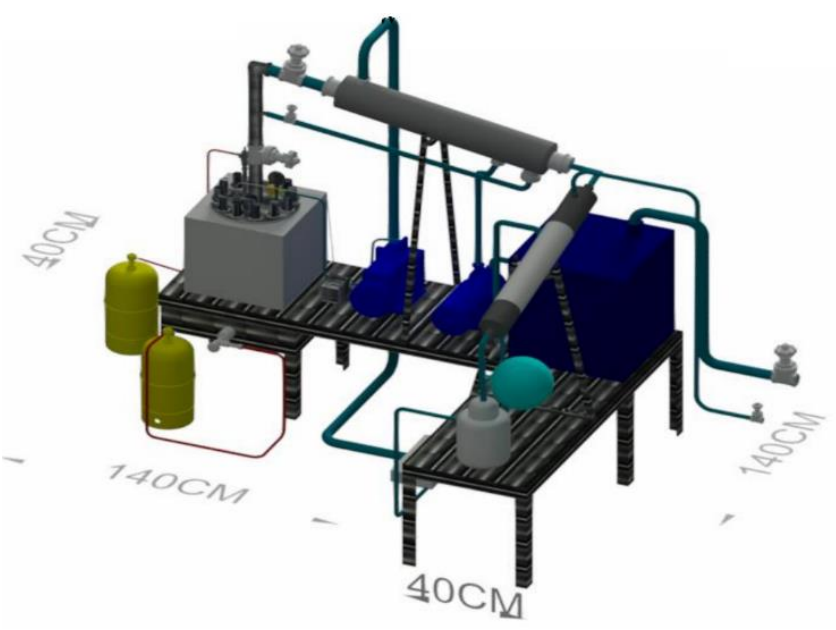

Fig. 4: 3D Simulated model of pyrolysis plant

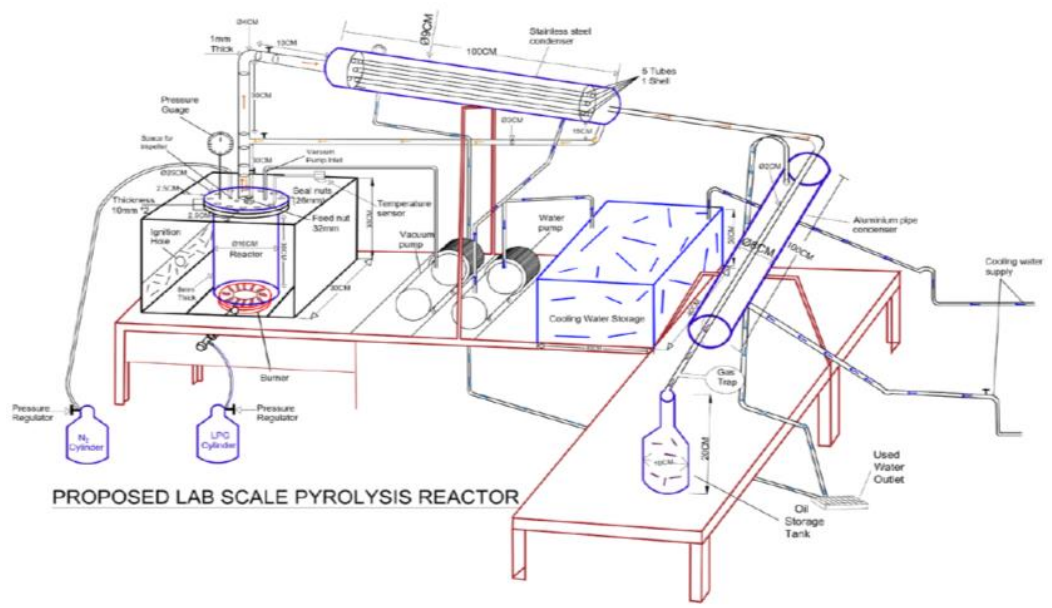

Fig. 5: Schematic diagram of the Lab-scale pyrolysis system 
Table 1: Summary of pyrolysis plant design dimension

\begin{tabular}{llll}
\hline S/N & Parameter & Value & Unit \\
\hline 1 & Height of the reactor & 300 & $\mathrm{~mm}$ \\
2 & Internal pressure & 1.2 & $\mathrm{Mpa}$ \\
3 & Corrosion Allowance (CA) & 1.5 & $\mathrm{Mm}$ \\
4 & Shell Internal Diameter (I.D) & 180 & $\mathrm{~mm}$ \\
5 & The thickness of the reactor & 8 & $\mathrm{~mm}$ \\
6 & Inlet/outlet cooling temperature (C1\&C2) & $15 / 60$ and $25 / 45$ & ${ }^{\circ} \mathrm{C}$ \\
7 & Inlet/outlet fluid temperature (C1\&C2) & $500 / 270$ and $287 / 62.7$ & ${ }^{\circ} \mathrm{C}$ \\
8 & Overall heat transfer coefficient (C1\&C2) & $\mathrm{W} / \mathrm{m}^{2} \mathrm{~K}$ \\
9 & Length of condenser pipes & $33 \& 201.56$ & $\mathrm{~mm}$ \\
10 & Number of tubes & 1000 & - \\
11 & Maximum Allowable pressure & 5 & $\mathrm{Mpa}$ \\
12 & Height of the outer box and distance to burner & 3.21 & $\mathrm{~mm}$ \\
13 & Total heat transfer rate/Area (C1\&C2) & 300 each & $\mathrm{W} / \mathrm{mm}$ \\
14 & Height of the burner & $37,800 / 3.38 \& 16,800 / 0.74$ & $\mathrm{~mm}$ \\
15 & Heating Value of LPG & 4 & $\mathrm{Kg} / \mathrm{J}$ \\
\hline
\end{tabular}

\section{Experimental Procedure}

The plastic wastes used were collected from different dumpsites in Edo north area of Edo State and downsized into pellets to reduce the void age in the reactor. The waste plastic pallets are weighed according to their plastic-type i.e., PE, PP, and HDPE to make up the comingled feed. The waste plastic pellets are then fed into the reactor through the feeding nut or by removing the top flange and then closing tightly. An attached vacuum pump is used to remove the contained air to avoid burning after which the system is pressurized with inert gas (Nitrogen) about 2 bar. The burners are lit to supply heat to the reactor while the temperature is monitored with the help of a thermocouple at the top of the reactor. The temperature is maintained at an optimal of $450^{\circ} \mathrm{C}$ as described by Abbas-Abadi et al. (2014). The resulting vaporized plastic flows through to the condensers at various temperatures where it is cooled using water. The cracked condensate from the first condenser is refluxed back to the reactor by closing and opening some valves because of its high molecular weight compounds. The final condensate from the second condenser is collected in an air-tight container. The uncondensed gas is trapped using an air trap balloon and sent and analyzed for prospective fuel capabilities in a further modified pyrolysis system. At the end of the reaction, the char is removed and weighed along with the volume of the collected pyrolysis oil. The oil is then purified by washing with water and decanted properly after which further purification is done by a filter paper. The PH is measured and rewashed accordingly to neutralize the oil. This entire process was modified after the first trial and then repeated three consecutive times before the performance was evaluated using the following formulas:

Oil Conversion Ef Ficiency $(C E) \%+=w^{0} / W_{S M} \times 100 \%$

Oil Recovery $(O R)={ }^{v} / W_{S M}$
Gas Yield $(\mathrm{kg})=$ Mass of Feed

-(Mass of Oil Recovered + Mass of Char $)$

where $W_{0}=$ Wieght of $\mathrm{Oil}, W_{s M}$

$=$ Wieght of Plastic and $V=$ Volume of Oil.

\section{Characterization of Plastic Oil}

Several physicochemical characteristics of the pyrolytic oil were determined according to ASTM standards and compared to standard fuel (diesel) properties. The density was measured using a $25 \mathrm{~mL}$ pycnometer at different temperatures and reported in $\mathrm{kg} / \mathrm{m}^{3}$. The calorific value was measured using the bomb calorimeter, and viscosity using the Ferranto portable viscometer. The ash content was measured along with the flashpoint, cloud point, pour point, and $\mathrm{pH}$ of the comingled pyrolytic oil.

\section{Results and Discussion}

\section{Waste Collection}

Figure 6 above shows the distribution of waste in the experimental sample obtained from Edo North. Polypropylene (PP) was the major constituent gotten majorly from buckets, jerry cans, paint rubbers, etc. High-Density Polyethylene (HDPE) had about $37.5 \%$ while Polystyrene (PS) was only $12.5 \%$ of the entire sample collected.

\section{Pyrolysis Experiment Result}

From Table 2 above, three runs of experiments for converting comingled municipal waste plastic of High-Density Polyethylene (HDPE), Polypropylene (PP), and Polystyrene (PS) into comingled pyrolytic oil were conducted. The first, second, and third tests yielded 1.70, 1.85 , and 1.80 liters of pyrolytic oil respectively. Similarly, $0.29,0.26$, and $0.27 \mathrm{~kg}$ of char were gotten during the first, second, and third tests respectively while $0.26,0.19$, and 0.17 $\mathrm{kg}$ of gas were gotten from the three runs consecutively. Equations (1), (2), and (3) were used to respectively calculate 
the actual performance of the comingled pyrolytic system using values as explained in Table 2 above forming Table 3.

\section{Conversion Efficiency}

From Table 4, it is discovered that an average of $73.17 \%$ of the whole waste plastic was converted into pyrolytic oil. This implies that an average of $13.5 \%$ of the waste plastic was converted into char while about $10 \%$ was converted into gas. In general, over $70 \%$ of the municipal waste plastic was converted into oil at each trial of the process with the entire pyrolytic system having an average overall conversion efficiency of $96.67 \%$. Similar efficiency results were achieved by Weldekidan et al. (2019) using chicken litter and rice husk as feed.

The heating rate also had a significant effect on the pyrolytic oil production rate. About $185 \mathrm{ml}$ more of oil was collected in the second experiment compared to the first one. This is possible because the heating rate was drastically increased in the second experiment as discovered by Jayswal et al. (2017) who discovered a similar occurrence.

\section{Characterization of Comingled Pyrolytic Oil}

The comingled pyrolytic oil obtained in this experiment was characterized and compared with those gotten from. The physicochemical properties of comingled oil are shown in Table 4.

\section{Calorific Value and Colour}

The comingled oil appeared reddish-orange while having a calorific value of $49.2 \mathrm{MJ} / \mathrm{kg}$ which is at least $3.2 \mathrm{MJ} / \mathrm{kg}$ higher than that of commercially used diesel (44-46 MJ/kg). Similar results were gotten by Wongkhorsub and Chindaprasert in 2013 when they compared the effects of pyrolytic oil in diesel engines. Calorific value is an important property of diesel fuels because it determines the energy content in the fuel. A higher calorific value indicates that a larger amount of energy is produced utilizing the comingled pyrolytic oil than in the use of diesel. According to Sharuddin et al.
(2018), the higher calorific value is a result of the presence of HDPE and PP as major constituents of the comingled plastic which have experimental calorific values of $40 \mathrm{MJ} / \mathrm{kg}$ and above. This makes the comingled pyrolytic oil suitable for a new energy resource in terms of energy content. The heating value of the comingled plastic-derived pyrolytic oil was also higher than those derived from tire and furnace oil.

\section{Density and Viscosity}

The density, which is defined as the mass of a unit volume of a material at a selected temperature (usually $15^{\circ} \mathrm{C}$ ) (Lois et al., 2003), of the comingled oil was lower than that of commercial diesel while the oils derived from tire and furnace. A similar result was reported by Lee et al. (2015). The viscosity however fell within the commercialgrade diesel range for the comingled pyrolytic oil. Viscosity is another very essential parameter to guarantee a good atomization property of a fuel (Lois et al., 2003). Lois et al. (2003); referenced that for automotive, 2.0-4.5 is the required range while a maximum of $6 \mathrm{CST}$ at $40^{\circ} \mathrm{C}$ is the heating maximum according to EN ISO 3104. This invariably means that the pyrolytic oil meets the standard for both heating fuels and automobiles.

\section{Flash Cloud and Pour Point}

Flashpoint is a very important property for the storage and handling of fuels (Lois et al., 2003). Diesel fuels are usually stable and do not require special preservation considerations; nevertheless, the flashpoint is a good indicator of diesel fuel contamination with some more volatile chemicals. Lois et al. (2003). Hence, a flashpoint as low as $24^{\circ} \mathrm{C}$ indicates a clean and environmentally friendly energy source as against that of significantly higher diesel $\left(>55^{\circ} \mathrm{C}\right)$ than the comingled pyrolytic oil $\left(24^{\circ} \mathrm{C}\right)$ making it a very preferable source of heating. The cloud and pour points however fall within the range for the commercial-grade diesel as shown in Table 4 above. A higher pour point $\left(-12^{\circ} \mathrm{C}\right)$ than that of diesel $\left(-40\right.$ to $\left.-33^{\circ} \mathrm{C}\right)$ is possibly indicative of a larger amount of paraffin in the feed (Motawie et al., 2015) which contains about 37.5\% HDPE.

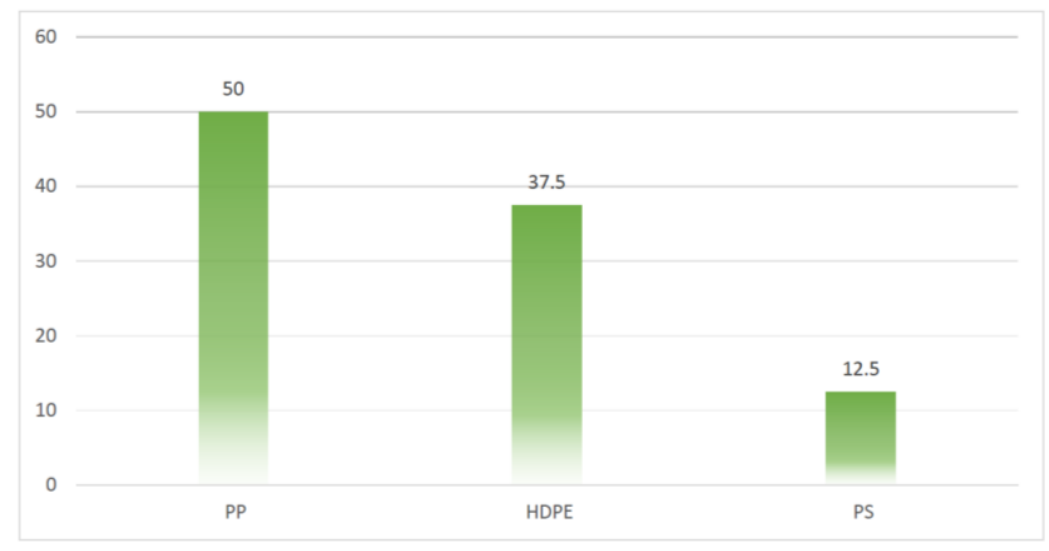

Fig. 6: Percentage distribution of municipal waste plastics sample from Edo North 
Table 2: Performance evaluation of comingled pyrolysis system

\begin{tabular}{|c|c|c|c|c|c|}
\hline \multirow[b]{2}{*}{ Parameters } & \multicolumn{3}{|c|}{ Trials } & \multirow[b]{2}{*}{ Total } & \multirow[b]{2}{*}{ Average } \\
\hline & 1 & 2 & 3 & & \\
\hline Weight of plastic $(\mathrm{Kg})$ & 2.00 & 2.00 & 2.00 & 6.00 & 2.00 \\
\hline Operation time (hrs) & 3.00 & 3.00 & 3.00 & 9.00 & 3.00 \\
\hline Volume of oil (L) & 1.70 & 1.85 & 1.80 & 5.45 & 1.81 \\
\hline Weight of oil $(\mathrm{Kg})$ & 1.40 & 1.51 & 1.48 & 4.39 & 1.46 \\
\hline Weight of Char (Kg) & 0.29 & 0.26 & 0.27 & 0.82 & 0.27 \\
\hline Weight of gas recovered $(\mathrm{kg})$ & 0.26 & 0.19 & 0.17 & 0.62 & 0.21 \\
\hline
\end{tabular}

Table 3: Performance evaluation of comingled pyrolysis system

\begin{tabular}{lllll}
\hline & Trials & & \\
& -1 & 2 & 3 \\
Parameters & 1 & 75.50 & 74.00 & Average \\
\hline Oil conversion efficiency (wt \%) & 70.00 & 0.925 & 0.900 & 73.17 \\
Oil recovery (L/Kg waste plastic) & 0.850 & 0.892 \\
\hline
\end{tabular}

Table 4: Physicochemical properties of pyrolytic oil

\begin{tabular}{|c|c|c|c|c|}
\hline Property & diesel & Tire derived oil & Furnace oil & Comingled oil \\
\hline Colour & Bright yellow & & & Reddish orange \\
\hline Density $\left(\mathrm{kg} / \mathrm{m}^{3}\right)$ & $820-860$ & $940-970$ & $880-950$ & 798 \\
\hline Flash point $\left({ }^{\circ} \mathrm{C}\right)$ & $>55$ & $\leq 32$ & $66-93$ & 24 \\
\hline Pour point $\left({ }^{\circ} \mathrm{C}\right)$ & -40 to -30 & -3 to -5 & $18-27$ & -12 \\
\hline Viscosity (cSt at $\left.40^{\circ} \mathrm{C}\right)$ & $2-4.5$ & $4.6-4.9$ & - & 3.26 \\
\hline Calorific value $(\mathrm{MJ} / \mathrm{kg})$ & $44-46$ & $40.8-42.5$ & $43-45$ & 49.2 \\
\hline Cloud point $\left({ }^{\circ} \mathrm{C}\right)$ & $>-40$ & _- & _- & -37.7 \\
\hline Ash content & $<0.01$ & - & - & $<0.004$ \\
\hline Sulphur content (ppm) & $<500$ & - & - & nil \\
\hline
\end{tabular}

In general, the ash content was extremely low which was described by Santaweesuk and Janyalertadun (2017) as evidence of the fluid's lack of metal pollution and high-molecular-weight soot. Agreeing with Wongkhorsub and Chindaprasert (2013) comingled pyrolytic oil can be used as liquid fuels for both industrial furnaces, power plants, boilers, and also diesel engines and can replace diesel fuels. They also found that, although plastic pyrolysis oil provides much-reduced engine performance, the engine may be adjusted to match the combustion state of comingled plastic pyrolysis oil. Furthermore, the volume of plastic trash is tremendous and it is environmentally important to treat it.

\section{Conclusion}

In conclusion, this study has proven that:

1. The pyrolysis system designed to utilize comingled feedstock from several types and grades of plastics was successful in producing pyrolytic oil

2. This thermal pyrolysis system produced a maximum of $75.5 \%$ pyrolytic oil among the three trials carried out and over $70 \%$ average pyrolytic conversion of plastic to oil

3. This pyrolysis setup gives an overall conversion efficiency of above $95 \%$ on average
4. The heating rate of the system largely affects the amount of oil extracted from the system as observed in the second trial of the system

5. The comingled pyrolytic oil has excellent fuel characteristics, including a high calorific value. $(49.20 \mathrm{MJ} / \mathrm{kg})$, density $\left(798 \mathrm{~kg} / \mathrm{m}^{3}\right)$, viscosity $(3.26 \mathrm{cSt})$, pour point $(-12)$ and flash point $\left(24^{\circ} \mathrm{C}\right)$

6. The comingled pyrolytic oil has close-ranged characteristics and qualities as diesel for heating and/or vehicles

\section{Acknowledgment}

The authors hereby acknowledge the technologists from the Department of Mechanical Engineering Workshop, Edo State University, Uzairue for their availability and valuable support during the design and fabrication stages of this research.

\section{Author's Contributions}

Kevin Otoikhian: Conceptualized the project, designed the pyrolyzer, participated in the experiment, analyzed and Interpretation of results, and reviewed the manuscript Draft.

Ubani Oluwaseun Amune: Analysis and Interpretation of Results, Draft, and Editing of Manuscript. 
Kennedy Edogamhe: Participated in the experiment and data collection.

Barnabas Agbodekhe: Conceptualization and design of pyrolyzer, Analysis, and interpretation of the result.

Emmanuel Aluyor: Conceptualization and design of pyrolyzer.

\section{Ethics}

This article is original and contains unpublished material. The corresponding author confirms that all of the other authors have read and approved the manuscript and that no ethical issues are involved.

\section{Declaration of Competing Interest}

The authors declare that they have no known competing financial interests or personal relationships that could have appeared to influence the work reported in this study.

\section{References}

Abbas-Abadi, M. S., Haghighi, M. N., Yeganeh, H., \& McDonald, A. G. (2014). Evaluation of pyrolysis process parameters on polypropylene degradation products. Journal of Analytical and Applied Pyrolysis, 109, 272-277. doi.org/10.1016/j.jaap.2014.05.023

Aisien, E. T., Otuya, I. C., \& Aisien, F. A. (2021). Thermal and catalytic pyrolysis of waste polypropylene plastic using spent FCC catalyst. Environmental Technology and Innovation, 22, 101455. doi.org/10.1016/j.eti.2021.101455

Amenaghawon, N., Aisien, F., \& Agho, O. (2013). Application of recycled rubber from scrap tires in the adsorption of toluene from aqueous solution. Journal of Applied Sciences and Environmental Management, 17(3). doi.org/10.4314/jasem.v17i3.10

Asoko (2017). Nigeria's Plastics Industry Is Fast Growing. https://www.pppnigeria.com/nigeriaplastic-print-packaging.html June 3, 2019

Holman, J. P. (2010). Heat transfer, 10th edit. McGrawHill Higher education.

Jambeck, J. R., Geyer, R., Wilcox, C., Siegler, T. R., Perryman, M. andrady, A., Narayan, R., \& Law, K. L. (2015). Plastic Waste Inputs from Land into the Ocean. Science, 347(6223), 768-771. doi.org/10.1126/science. 1260352

Jayswal, A., Sah, A. K., Pradhananga, P., Sah, R., \& Darlami, H. B. (2017). Design, Fabrication, and Testing of Waste Plastic Pyrolysis Plant. In Proceedings of $5^{\text {th }}$ IOE Graduate Conference.

Kutz, M. (2006). Heat-transfer calculations. McGraw-Hill Education.
Kyaw, K. T., \& Hmwe, C. S. S. (2015). Effect of various catalysts on fuel oil pyrolysis process of mixed plastic wastes. International Journal of Advances in Engineering and Technology, 8(5), 794. file:///C:/Users/PC/Downloads/12I29IJAET0829561-v8-iss5-794-802.pdf

Lee, S., Chen, L., Yoshida, K., \& Yoshikawa, K. (2015). Application of Waste Biomass Pyrolysis Oil in a Direct Injection Diesel Engine: For a Small Scale Non-Grid Electrification. Journal of Energy and Power Engineering, 9(11). doi.org/10.17265/1934-8975/2015.11.002

Lois, E., Keating, E. L., \& Gupta, A. K. (2003). Fuels. Encyclopedia of Physical Science and Technology, 275-314. doi.org/10.1016/b0-12-227410-5/00268-4

Ma, C., Yu, J., Wang, B., Song, Z., Xiang, J., Hu, S., Su, S., \& Sun, L. (2017). Catalytic pyrolysis of flame retarded high impact polystyrene over various solid acid catalysts. Fuel Processing Technology, 155, 32-41. doi.org/10.1016/j.fuproc.2016.01.018

Macedonia, F. Y. R. (2016). Evaluation of density and viscosity of blends of waste plastic pyrolysis oil and commercially diesel fuel. Journal of Environmental Protection and Ecology, 17(3), 1142-1151.

Matsuzawa, Y., Ayabe, M., \& Nishino, J. (2001). Acceleration of cellulose co-pyrolysis with polymer. Polymer Degradation and Stability, 71(3), 435-444. doi.org/10.1016/s0141-3910(00)00195-6

Miandad, R., Rehan, M., Barakat, M. A., Aburiazaiza, A. S., Khan, H., Ismail, I. M. I., Dhavamani, J., Gardy, J., Hassanpour, A., \& Nizami, A.-S. (2019). Catalytic Pyrolysis of Plastic Waste: Moving Toward Pyrolysis Based Biorefineries. Frontiers in Energy Research, 7. doi.org/10.3389/fenrg.2019.00027

Motawie, M., Hanafi, S. A., Elmelawy, M. S., Ahmed, S. M., Mansour, N. A., Darwish, M. S. A., \& Abulyazied, D. E. (2015). Wax co-cracking synergism of high-density polyethylene to alternative fuels. Egyptian Journal of Petroleum, 24(3), 353-361. doi.org/10.1016/j.ejpe.2015.07.004

Panda, A. K. (2018). Thermo-catalytic degradation of different plastics to drop in liquid fuel using calcium bentonite catalyst. International Journal of Industrial Chemistry, 9(2), 167-176. doi.org/10.1007/s40090-018-0147-2

Patni, N., Shah, P., Agarwal, S., \& Singhal, P. (2013). Alternate Strategies for Conversion of Waste.

Santaweesuk, C., \& Janyalertadun, A. (2017). The production of fuel oil by conventional slow pyrolysis using plastic waste from a municipal landfill. International Journal of Environmental Science and Development, 8(3), 168-173. doi.org/10.18178/ijesd.2017.8.3.941 
Scheirs, J., \& W Kaminsky. (2006). Feedstock recycling and pyrolysis of waste plastics: Converting waste plastics into diesel and other fuels. J. Wiley and Sons.

Sharuddin, S. D. A., Abnisa, F., Daud, W. M. A. W., \& Aroua, M. K. (2018). Pyrolysis of plastic waste for liquid fuel production as a prospective energy resource. IOP Conference Series: Materials Science and Engineering, 334, 012001. doi.org/10.1088/1757-899x/334/1/012001

Weldekidan, H., Strezov, V., He, J., Kumar, R., Asumadu-Sarkodie, S., Doyi, I. N. Y., Jahan, S., Kan, T., \& Town, G. (2019). Energy Conversion Efficiency of Pyrolysis of Chicken Litter and Rice Husk Biomass. Energy and Fuels, 33(7), 6509-6514. doi.org/10.1021/acs.energyfuels.9b01264

Williams, P. T., \& Slaney, E. (2007). Analysis of products from the pyrolysis and liquefaction of single plastics and waste plastic mixtures. Resources, Conservation and Recycling, 51(4), 754-769. doi.org/10.1016/j.resconrec.2006.12.002

Wongkhorsub, C., \& Chindaprasert, N. (2013). A comparison of the use of pyrolysis oils in diesel engine. Energy and Power Engineering, 05(04), 350-355. doi.org/10.4236/epe.2013.54b068

\section{Appendix}

\section{Pyrolysis System Design Calculations}

\section{Reactor Shell Design Calculations}

Internal pressure $=1.2 \mathrm{MPa}$ about $10.2 \mathrm{Bar}$

Corrosion Allowance $(\mathrm{CA})=1.5 \mathrm{~mm}$

Shell Internal Diameter (I.D) $=1$

Allowable Stress $(\mathrm{S})=70 \mathrm{MPa}$

Static Head $=0.05 \mathrm{MPa}-0.5 \mathrm{Bar}$

Design pressure $(\mathrm{P})=$ internal Pressure + Static Head

$1.2+0.05=1.25 \mathrm{MPa}$

Joint efficiency $(\mathrm{E})=0.7$

Corroded Diameter $=$ I.D $+2^{*}$ C.A $180+2^{*} 1.5=187.5 \mathrm{~mm}$

Design Radius $(r)=187.5 / 2=93.75$

Required thickness $t r=P * r S * E-0.6 * P$

i.e. $t r=1.25 * 93.7570 * 0.7-0.6 * 1.25 /=2.43 \mathrm{~mm}$

Design thickness $=t r+C$.A i.e., $2.43+1.5=3.93 \mathrm{~mm}$

Considering that the pyrolysis reactor will operate at a temperature of over $500^{\circ} \mathrm{C}$, for safety reasons, the calculated thickness of the reactor shell has been increased to $8 \mathrm{~mm}$

Thickness $=\mathrm{t}=\mathrm{tn}-\mathrm{C} . \mathrm{A}=8-1.5=6.5$

\section{For Maximum Allowable Pressure Calculation}

According to MAWP standards defined by the international organization for standardization

$$
\begin{aligned}
& P={ }^{S * E}{ }^{*} t / r+0.6 * t, p=70 * 0.7 * \\
& 6.5 / 93.75+0.6 * 6.5 \therefore P=3.26 \mathrm{MP} \alpha
\end{aligned}
$$

Maximum Allowable pressure $=\mathrm{P}-$ Static Head i.e., $3.26-0.05=3.21 \mathrm{MPa}$

\section{Reactor Design}

Heating Value of LPG per $\mathrm{kg}(\mathrm{QHv})=46100$

Specific heat capacity of pyrolysis oil $(\mathrm{Cp})=2400 \mathrm{~J} / \mathrm{kg} . \mathrm{k}$ Specific heat capacity of water $(\mathrm{Cpw})=4200 \mathrm{~J} / \mathrm{kg} \cdot \mathrm{k}$ The average value of heat of fusion of Polyethyene (PE) Heat requirement for pyrolysis plus vaporization of $2 \mathrm{~kg}$ liquid $\mathrm{PE}=1047.62 \mathrm{KJ}$

LPG stove efficiency $=51.3 \%$

Latent heat of vaporization of LDPE $=180.46 \mathrm{~J} / \mathrm{kg}$

Assume that time for complete pyrolysis $=2 \mathrm{~h}$

$D_{o}=8 \mathrm{~cm}$

$D_{1}=1 \mathrm{~cm}$

$\mathrm{K}_{\text {tube }}=15 \mathrm{~W} / \mathrm{m} \cdot \mathrm{k}$

Viscosity of water $\mu=855 * 10-6($ N.S $) \mathrm{m}^{2}$ Thermal conductivity of water $K_{w}=0.613 \mathrm{~W} / \mathrm{m} . \mathrm{k}$ )

Temperature claculations:

\section{For Condenser 1 (Cl)}

Ambient Temperature $T_{a}=25^{\circ} \mathrm{C}$ Temperature of Hot oil $\mathrm{T}_{\mathrm{HI}}=500^{\circ} \mathrm{C}$ Oil outlet temperature $T_{H O}=$ ?

Water inlet temperature $T_{W I}=15^{\circ} \mathrm{C}$

Water outlet temperature $T_{W O}=60^{\circ} \mathrm{C}$

\section{For Condenser 2 (C2)}

Ambient Temperature $\mathrm{Ta}=25^{\circ} \mathrm{C}$ The temperature of Hot oil $T_{H I}=$ ?

Oil outlet temperature $T_{H O}=$ ?

Water inlet temperature $T_{W I}=25^{\circ} \mathrm{C}$

Water outlet temperature $T_{W o}=45^{\circ} \mathrm{C}$

Heat taken by $10 \mathrm{~kg}$ solid plastic till it starts to melt at $110^{\circ} \mathrm{C}$ i.e., $Q 1=M * C p * \Delta T=1785 \mathrm{KJ}$

Heat requirement to completely melt $10 \mathrm{~kg}$ plastic at $110^{\circ} \mathrm{C}$, i.e., $Q 2=M * L f=1213.65 \mathrm{KJ}$

The heat required by $10 \mathrm{~kg}$ liquid plastic to reach $450-500$ $0 \mathrm{C}$ i.e., $Q 3=M * C p * \Delta T=7140 \mathrm{KJ}$

The heat required for Pyrolysis $\left(\mathrm{Q}_{4}\right)=$ mass $*$ Heat requirement for pyrolysis plus vaporization

$=10 \mathrm{~kg} * 1047.62 \mathrm{KJ} / \mathrm{kg}=10476.2 \mathrm{KJ}$

Total heat required $=Q_{1}+Q_{2}+Q_{3}+Q_{4}=20,614.25 \mathrm{KJ}$

Heat transfer rate required $=$ Total heat requiredtiment taken:

$$
\text { i.e. } 20614.85 / 2=10307.4 K J / h r
$$

Plastic vapor production rate $=$ heat transfer rate latent heat of vaporization:

$$
\text { i.e. } 10307.4 / 18.46=57.12 \mathrm{Kg} / \mathrm{hr}
$$

$57.12 \mathrm{~kg} / \mathrm{hr} * 0.000278=0.016$ i.e., approximately 0.02 $\mathrm{kg} / \mathrm{secs}$ 
Heat Exchanger Design for Condenser 1 (C1) (Holman, 2010 and Kutz, 2006)

$$
\begin{aligned}
& Q=0.02 * 2.4 * 103\left(500-T_{\text {НО }}\right) 0.2 * 4.2 * 103(60-15) \\
& Q=24000 * 48 T h o=378000 \\
& T_{H O}=13000 / 48, T_{\text {HО }}=48 T_{\text {НО }}
\end{aligned}
$$

\section{Heat Exchanger Design for Condenser 2}

$$
\begin{aligned}
& Q=m h^{*} C p h(T H I-T H O)=m c^{*} C p w(T H I-T H O) \\
& Q=0.02 * 2.4 * 103\left(287.5-T_{W O}\right)=0.2 * 4.2 * 103(45-25) \\
& Q=13800 * 48 \mathrm{~T}_{H O}=16800 \\
& T_{H O}=\frac{3000}{48}=6.25^{\circ} \mathrm{C}
\end{aligned}
$$

Logarithmic Mean Temperature Difference for condenser 1:

$$
\begin{aligned}
& \Delta T m={ }^{\left(T h_{1}-T w_{O}\right)-\left(T h_{1}-T w_{O}\right)} / \operatorname{In}\left(\frac{\left(T h_{1}-T w_{O}\right)}{\left.\left(T h o-T w_{1}\right)\right)}\right. \\
& \Delta T m={ }^{(500-60)-(287.5-15)} / \operatorname{In}\left(\frac{500-60}{287.5-15}\right), \Delta T m=349^{\circ} \mathrm{C}
\end{aligned}
$$

Logarithmic Mean Temperature Difference for condenser 2:

$$
\begin{aligned}
& \Delta T m={ }^{\left(T h_{1}-T w_{O}\right)-\left(T h_{1}-T w_{O}\right)} / \operatorname{In}\left({\frac{\left(T h_{1}-T w_{O}\right)}{h}}_{(T O-T w I)}\right. \\
& \Delta T m={ }^{(287.5-45)-(62.5-25)} / \operatorname{In}\left(\frac{287.5-45}{62.5-25}\right), \Delta T m=109.8^{\circ} \mathrm{C}
\end{aligned}
$$

\section{Overall Heat Transfer Coefficient Calculation for Condenser 1}

$$
U=\left[1 / \frac{d o}{d i} * \frac{1}{h i}+\frac{d o}{k} * \operatorname{In} \frac{d o}{d i}+\frac{1}{h o}\right]
$$

When fouling factor and scale formation are neglected the overall heat transfer coefficient based on the outer surface and inner surface of the tube is given above.

For the heat transfer coefficient based on inner pipe hi The vapor properties of pyrolysis oil according to (Wongkhorsub and Chindaprasert, 2013) include;

Density $\rho=814.7 \mathrm{~kg} / \mathrm{m}^{2}$

Viscosity $v=0.00249 \mathrm{Kj} / \mathrm{kg}$

Thermal conductivity of pyrolysis oil $\mathrm{K}=0.17 \mathrm{w} / \mathrm{m} . \mathrm{k}$ Specific heat capacity of pyrolysis oil vapor $\mathrm{Cp}=2.40$ $* 10^{3}$ (Jayswal et al., 2017)
The mass flow rate of the pyrolysis vapor $(\mathrm{m})=0.02 \mathrm{~kg} / \mathrm{s}$ Diameter of the inner tube $=0.01 \mathrm{~m}$

$$
\begin{aligned}
& \operatorname{Pr}=v C p / k, \operatorname{Pr}+=0.00249 * 2.40 * 10^{3} / 0.17=35.15 \\
& \operatorname{Re}=\frac{4 m}{\pi d v}, \operatorname{Re}=4 * 0.02 /{ }_{\pi^{*} 0.01 * 0.00249}=1022.68 \\
& \mathrm{Nu}=0.023 \operatorname{Re}^{0.8}{ }_{*} \operatorname{Pr}^{0.4}, N u=0.023 *(1022.68)^{0.8} * 35.15^{0.4}, N u=24.38 \\
& h i=(k / d), \mathrm{hi}=24.38\left(\left(^{0.17} / 0.01\right), \mathrm{hi}=414.46 \mathrm{w} / \mathrm{m} 2 . \mathrm{K}\right.
\end{aligned}
$$

For the heat transfer coefficient based on outer pipe ho:

$$
h o=0.725\left(\left(^{\rho(\rho-* \rho)} * g * h f g * k_{f}^{3} / u f * d\left(T_{G}-T_{O}\right)^{\frac{1}{4}}\right.\right.
$$

From the table of the physical characteristics of water,

Density $\rho$ of water @ $15 \mathrm{oC}=999 \mathrm{~kg} / \mathrm{m} 2$

Viscosity $v$ of water @ $15 \mathrm{oC}=0.001139 \mathrm{Kj} / \mathrm{kg}$

Thermal conductivity of water $\mathrm{k}=0.613 \mathrm{w} / \mathrm{m} . \mathrm{k}$

Specific heat capacity of water $\mathrm{Cp}=4.186 * 103$

Gravitational acceleration $\mathrm{g}=9.81 \mathrm{~m} / \mathrm{s}^{2}$

Enthalpy difference between gas and fluid $h_{\mathrm{fg}}=2255 \mathrm{kj} / \mathrm{kg}$

Outer diameter $=0.08$

$$
\begin{aligned}
& \text { ho } \left.=0.725\left(999^{2} * 9.81 * 2255 * 10^{3} * 0.613^{3} / 0.001139\right) * 0.08 *(60-15)\right) \frac{1}{4}, \text { ho } \\
& =4302.4^{w} / \mathrm{m} 2 . K
\end{aligned}
$$

Overall heat transfer coefficient for condenser 1;

$$
\begin{aligned}
& U=\left[1 / \frac{d o}{d i} * \frac{1}{h i}+\frac{d o}{k} * \operatorname{In} \frac{d o}{d i}+\frac{1}{h o}\right] \\
& U=\left[1 / \frac{0.08}{0.01} * \frac{1}{414.46}+\frac{0.8}{15} * \operatorname{In} \frac{1}{4302.4}\right], U=33^{W} / \mathrm{m}^{2 \cdot k}
\end{aligned}
$$

Evaluating for the Area of condenser 1:

$$
\begin{aligned}
& Q=U A \Delta T m, A=Q / U * \Delta T m \\
& \mathrm{U}=33^{w} / m 2 . K, \mathrm{Q}=37800 \mathrm{~W}, \Delta T m= \\
& 349^{\circ} \mathrm{C}, A={ }^{37800} / 33 * 349, \mathrm{~A}=3.38 \mathrm{~m}
\end{aligned}
$$

Evaluating for the length of the heat exchanger $L=A / \pi *$ $d 1 * 2 * n t$ where

$\mathrm{A}=$ the area of the heat exchanger $D i=$ the inner diameter of the tube $n t=$ the number of tubes in the shell and tube heat exchanger:

$$
L={ }^{3.28} / \pi * 0.01 * 2 * 5, \quad L=100 \mathrm{~cm}=1 \mathrm{~m}
$$

Overall heat transfer coefficient calculation for condenser 2 : 


$$
U=\left[1 / \frac{d o}{d i} * \frac{1}{h i}+\frac{d o}{k} * \operatorname{In} \frac{d o}{d i}+\frac{1}{h o}\right]
$$

When fouling factor and scale formation are neglected the overall heat transfer coefficient based on the outer surface and inner surface of the tube is given above.

For the heat transfer coefficient based on inner pipe hi The vapor properties includes

Density $\rho=814.7 \mathrm{~kg} / \mathrm{m}^{2}$

Viscosity $v=0.00249 \mathrm{kj} / \mathrm{kg}$

Thermal conductivity of pyrolysis oil $\mathrm{k}=0.17 \mathrm{w} / \mathrm{m} . \mathrm{k}$

Specific heat capacity of pyrolysis oil vapor $C p=2.40$ $* 10^{3}$

The mass flow rate of the pyrolysis vapor $(\mathrm{m})=0.25 \mathrm{~kg} / \mathrm{s}$ Diameter of the inner tube $=0.02 \mathrm{~m}$ :

$$
\begin{aligned}
& \operatorname{Pr}=v c C p / k, \operatorname{Pr}=0.00249 * 2.40 * 10^{3} / 0.17=35.15 \\
& \operatorname{Re}=4 m / \pi d v, \operatorname{Re}+=4 * 0.25 /_{\pi^{*} 0.02 * 0.00249}={ }^{6391.76} \\
& \operatorname{Re}={ }^{4 m} / \pi d v, \operatorname{Re}={ }^{4 * 0.25} / 4 * 0.02 * 0.00249=6391.76 \\
& N u=0.023 \operatorname{Re}^{0.8} * \operatorname{Pr}^{0.4}, N u=0.023 *(6391.76)^{0.8} * 35.15^{0.4}, \\
& N u=115 h i=h i=115\left({ }^{0.17} / 0.02\right), \text { hi }=977.5^{W} / m 2 . k
\end{aligned}
$$

For the heat transfer coefficient based on outer pipe ho:

$$
h o=0.725\left(\left(^{\rho\left(\rho-\rho_{*}\right)} * g * h f g * k_{f}^{3} / u f * d\left(T_{G}-T_{O}\right)^{\frac{1}{4}}\right.\right.
$$

From the table of the physical properties of water, Density $\rho$ of water @ $27^{\circ} \mathrm{C}=996.59 \mathrm{~kg} / \mathrm{m} 2$ Viscosity $v$ of water @ $27^{\circ} \mathrm{C}=0.00852 \mathrm{Kj} / \mathrm{kg}$ Thermal conductivity of water $\mathrm{k}=0.613 \mathrm{w} / \mathrm{m} . \mathrm{k}$ Specific heat capacity of water $\mathrm{Cp}=4.186 * 103$ Gravitational acceleration $\mathrm{g}=9.81 \mathrm{~m} / \mathrm{s}^{2}$ Enthalpy difference between gas and fluid $\mathrm{Hfg}=2255$ $\mathrm{kj} / \mathrm{kg}$

Outer diameter $=0.08$ :

$$
\begin{aligned}
& h o=0.725\left(996.59^{2} * 9.81 * 2255 * 10^{3 *} * 0.613^{3} / 0.00852 * 0.08 *(45-25)\right)^{\frac{1}{4}} \\
& h o=3182.4 \frac{\mathrm{W}}{\mathrm{m}^{2}} . K
\end{aligned}
$$

Overall heat transfer coefficient for condenser 2:

$$
\begin{aligned}
& U=\left[1 / \frac{d o}{d i} * \frac{1}{h i}+\frac{d o}{k} * \operatorname{In} \frac{d o}{d i}+\frac{1}{h o}\right] \\
& U=\left[1 / \frac{0.08}{0.02} * \frac{1}{977.5}+\frac{0.8}{230} * \operatorname{In} \frac{0.8}{0.02}+\frac{1}{3182.4}\right], U=201.56 \mathrm{~W} / \mathrm{m}^{2 . k}
\end{aligned}
$$

Evaluating for the Area of condenser 2

$\mathrm{Q}=\mathrm{UA} \Delta T m$

$Q \mathrm{U} * \Delta T m, \mathrm{U}=204.56^{w} / m 2 . K, \mathrm{Q}=16800 \mathrm{~W}, \Delta T m=109.8^{\circ} \mathrm{C}$,

$A=$

$A=16800 / 204.56 * 109.8, \mathrm{~A}=0.74 \mathrm{~m}$

Evaluating the length of the heat exchanger, $L=A / \pi * d$ Where

$A=$ the area of the heat exchanger $d=$ the inner diameter of the tube

i.e., $L={ }^{0.74} / \pi * 0.02, L=110 \mathrm{~cm}=1.1 \mathrm{~m}$ 